\title{
GEOCHEMICAL ATLASES OF EUROPE PRODUCED BY THE EUROGEOSURVEYS GEOCHEMISTRY EXPERT GROUP: STATE OF PROGRESS AND POTENTIAL USES
}

\author{
Demetriades A. ${ }^{1}$, Reimann C. ${ }^{2}$, Birke M. ${ }^{3}$, Salminen R. ${ }^{4}$, De Vos W. ${ }^{5}$, \\ Tarvainen, T. ${ }^{4}$ and the EuroGeoSurveys Geochemistry Expert Group ${ }^{6}$ \\ ${ }^{1}$ Institute of Geology and Mineral Exploration, 1 Spirou Louis Street, Entrance C, Olympic Village, \\ 13677 Acharnae, Attiki, Hellas, ademetriades.igme.gr \\ ${ }^{2}$ Geological Survey of Norway, 39 Leiv Eirikssons, 7040 Trondheim, Norway, Clemens.Reimann@ ngu.no \\ ${ }^{3}$ Bundesanstalt für Geowissenshaften und Rohstoffe, Stilleweg 2, D-30655 Hannover, Germany, \\ Manfred.Birke@bgr.de \\ ${ }^{4}$ Geological Survey of Finland, P.O.Box 96, FI-02151 Espoo, \\ Finland,reijo.salminen@gtk.fi,timo.tarvainen@gtk.fi \\ ${ }^{5}$ Geological Survey of Belgium, Jannestraat 13, B-1000 Brussels, Belgium, \\ walter.devos@naturalsciences.be \\ ${ }^{6}$ EuroGeoSurveys Geochemistry Expert Group, Rue Joseph II 36-38, 1000 Brussels, Belgium, \\ www.eurogeosurveys.org
}

\begin{abstract}
An 'Atlas' is a collection of maps usually published in a book form. A 'Geochemical Atlas' is a thematic special purpose atlas with maps describing the geographical distribution of chemical elements and other physico-chemical parameters in different natural sample media, such as stream sediment, overbank or floodplain sediment, stream water, ground water, soil, plants, etc. Because our standard of living and health depend closely on the chemistry of near-surface materials, such atlases that provide data on the state of our environment are important for policy and decision makers, but also for researchers and citizens alike. The EuroGeoSurveys Geochemistry Expert Group is dedicated to provide harmonised multi-purpose geochemical data bases, and has already published the Geochemical Atlas of Europe, and is in the process of preparing the Atlas of Ground water Geochemistry of Europe, and the Atlas of Agricultural and Grazing Land Soils. An important aspect is that all raw data, quality control information, statistics, maps and interpretation texts are freely available for downloading through the internet.
\end{abstract}

Key words: geochemical atlas, stream water, ground water, bottled water, soil, overbank sediment, floodplain sediment, harmonisation of methods, INSPIRE, REACH, Europe.

\section{Introduction}

Let us start from the right beginning! What is an Atlas? According to Encyclopaedia Britannica (2010) an atlas is 'a collection of maps or charts, usually bound together'. Where does this name come from? The name is derived from a custom, which was initiated by Gerardus Mercator, the Flemish cartographer $(1512-1594)$, in the $16^{\text {th }}$ century who used the figure of the 
Titan Atlas, holding the globe on his shoulders, as a frontispiece for his books of maps. Who was the Titan Atlas? According to Hesiod's Theogony, Atlas was the son of Titan Iapetus and the Oceanid Clymene (or Asia) and brother of Prometheus (creator of humankind). He was one of the Titans who took part in their war against Zeus (the chief deity of the Pantheon, the Hellenic Olympian Gods). Upon loosing the war, Zeus for his punishment condemned him to support the pillars that held heaven and earth apart. The place was probably the highest peak of the Atlas Mountains in north-west Africa.

The 'Atlas' over time has evolved, and in addition to maps and charts, Atlases often contain pictures, tabular data, facts about areas, and indexes of place-names keyed to coordinates of latitude and longitude or to a locational grid with numbers and letters along the sides of maps. Thematic, or special purposes, Atlases deal primarily with a single subject, such as agriculture, geology, climate, history, industry, languages, population, religions, resources, or other characteristics of a geographical area. One such thematic category is 'Applied Geochemistry', a discipline that can indeed produce many different thematic atlases, containing a multitude of maps showing the geographical distribution of chemical elements in different sample media, such as stream sediment, overbank or floodplain sediment, stream water, ground water, soil, plants, etc.

Why are Geochemical Atlases important? The answer is given by Darnley et al. (1995, p.X) 'Everything in and on the earth - mineral, animal and vegetable - is made from one, or generally some combination of, the 90 naturally occurring chemical elements. Everything that is grown, or made, depends upon the availability of the appropriate elements. The existence, quality and survival of life depend upon the availability of elements in the correct proportions and combinations. Because natural processes and human activities are continuously modifying the chemical composition of our environment, it is important to determine the present abundance and spatial distribution of the elements across the Earth's surface in a much more systematic manner than has been attempted hitherto'. Systematic geochemical mapping is, therefore, considered as the best available method to document changes in the levels of chemical elements in materials occurring at or below the Earth's surface.

Where can Geochemical Atlases be used? The systematic geochemical information in the atlases can be used for (a) state of the environment reports, (b) mineral exploration, (c) agriculture, (d) forestry, (e) animal husbandry, (f) geomedicine or medical geology, (g) determination of natural background values for environmental risk assessment, etc. The list of end-users is, in fact, very long, when it is realised by policy makers and regulators that our living and working environment, and humans themselves, depend on the chemical composition of near-surface earth materials. What is required is education from the primary school age to university that our health and quality of life depend, to a large extent, on the chemical composition of our environment. When we understand how significant the above statement by Darnley et al. (1995) is, then we will begin to use efficiently the information in Geochemical Atlases.

\section{The EuroGeoSurveys Geochemistry Expert Group}

The EuroGeoSurveys Geochemistry Expert Group (EGS Geochemistry Group) has been in existence, under different names and forms of the association of European Geological Surveys, since 1986, i.e., Working Group on Regional Geochemical Mapping (Western European Geological Surveys, WEGS), Geochemistry Task Group (Forum of European Geological Surveys, FOREGS), Geochemistry Working Group and finally Geochemistry Expert Group under EuroGeoSurveys, the Association of Geological Surveys of Europe (http://www.eurogeosurveys.org/). 
The EGS Geochemistry Group has always been very active and forward in its proposals to the European Geological Survey Directors. It has carried out considerable research work on the harmonisation of sampling, sample preparation, laboratory analysis of samples, quality control of methods, and has produced many reports and publications, which can be viewed at http://www. gtk.fi/publ/foregsatlas/ and http://www.globalgeochemicalbaselines.eu/.

Presently, the EGS Geochemistry Group has undertaken to carry out many significant projects, including (i) the geochemical mapping of agricultural and grazing land soil, (ii) geochemistry of ground water, (iii) urban geochemical mapping of selected cities, (iv) publication of a book on the chemistry of urban environments, and many other initiatives. An important aspect of all these projects is that of harmonisation of methodologies, since this is the only way to produce comparable results across political boundaries, and to comply with the European Union's INSPIRE directive (Infrastructure for Spatial Information in the European Community at http://inspire.jrc.ec.europa.eu/).

\section{Geochemical Atlas of Europe}

Since the 1950s Geological Surveys have been documenting the natural geochemical background variation of chemical elements in a variety of sample materials, mainly for mineral exploration purposes (Garrett et al., 2008). The generated data at the national scale are often not comparable at the European scale (different sampling strategies, different materials and equipment used for sampling and sample preparation, different sample preparation protocols, different analytical protocols, etc.), and are, therefore, not able to provide a harmonised pan-European or Global geochemical 'baseline' (Bölviken et al., 1996). A reference network is, therefore, needed, where local data can be tied into European and Global scale data. International collaboration assisted UNESCO to establish in 1988 the IGCP 259 'International Geochemical Mapping' project and presently the IUGS/IAGC 'Global Geochemical Baselines' project, the aims of which are to establish a harmonised global geochemical reference baseline for over 60 determinands in different sample media for environmental and resource applications (Darnley et al., 1995; Darnley, 1997; Demetriades, 1998). The terrestrial surface of the Earth was divided into 5000 grid cells of 160 x $160 \mathrm{~km}$ (area 25,600 km²), and named the Global Reference Network (GRN). Although the proposed sampling density is low, approximately one sample site per five thousand square kilometres $\left(1\right.$ site $/ 5000 \mathrm{~km}^{2}$ ), applied geochemists have been using quite effectively such lowsample density surveys to cover large areas for the last forty years.

The EGS Geochemistry Expert Group, as an input to the global project, carried out the geochemical baseline survey in 26 European countries, according to an agreed field sampling protocol (Salminen, Tarvainen et al., 1998). Samples of stream water, stream sediment, topsoil, subsoil, floodplain sediment and humus from approximately 800 drainage basins, identified on the Global Reference Network within Europe, were collected, using the agreed standardised field sampling methods (Demetriades et al., 2008; Fedele et al., 2008; Lima et al., 2008).

Following sample preparation, all samples were sent to Slovakia for homogenisation and splitting into subsamples for analysis. All samples were subsequently analysed for the same suite of determinands at the same laboratory, since this is the only way to produce comparable results. Chemical analysis of all samples was completed in 2004, and data subsequently collated and examined for error, and determinand distribution maps plotted by the Geological Survey of Finland. Maps and introductory texts were published in Part 1 (Salminen et al., 2005), and the interpretation, together with specialised papers, included in Part 2 (De Vos, Tarvainen et al., 2006). 

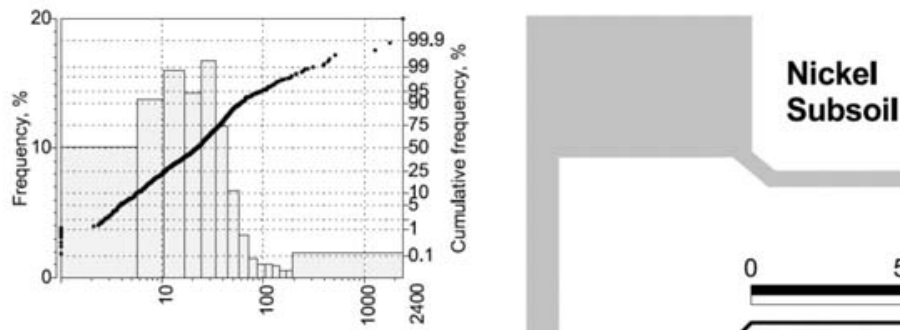

$\mathrm{Ni}$

$$
\mathrm{Ni}
$$

ICP-MS, detection limit $2 \mathrm{mg} \mathrm{kg}^{-1}$ Number of samples 792 Median $21.8 \mathrm{mg} \mathrm{kg}^{-1}$

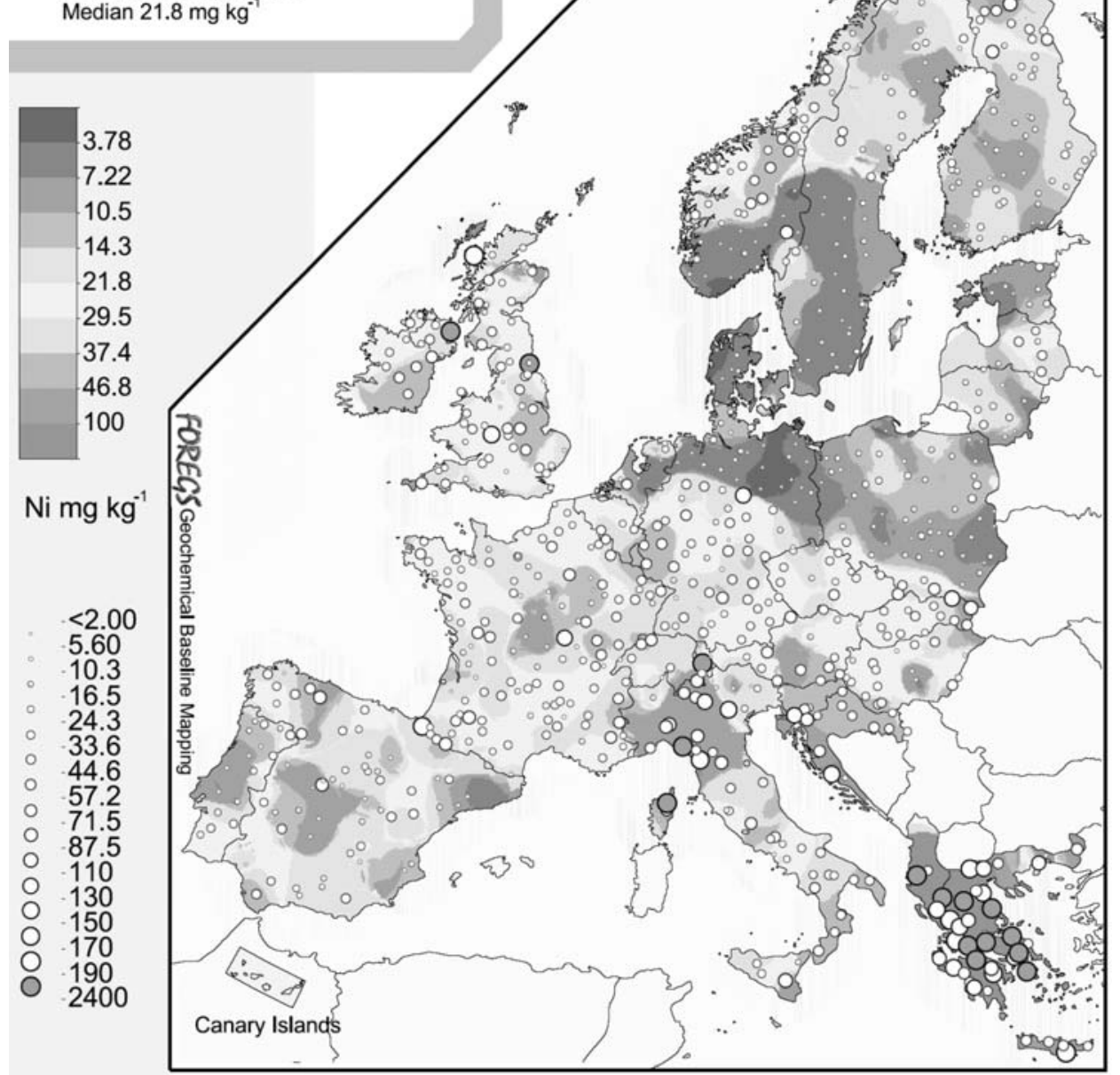

Fig. 1: Geochemical distribution of total Ni in the $<2 \mathrm{~mm}$ fraction of soil $>50 \mathrm{~cm}$ depth (Salminen et al., 2005, p.357).

Both parts, including analytical data and photograph archive can be downloaded from URL http://www.gtk.fi/publ/foregsatlas/. The two volume atlas contains about 400 thematic maps describing the geochemistry of surface materials in Europe, and one example is given below. 


\subsection{Distribution of nickel $(\mathrm{Ni})$ in subsoil}

High Ni values in subsoil occur in areas with mafic/ultramafic substrate, such as Hellas, Albania, Liguria (Italy) and Corsica, N. Ireland (Antrim plateau basalt), central Norway and northern Scandinavia with greenstone belts (Fig. 1). There are pronounced differences in subsoil between northern (low) and southern (high) Europe. The break follows the maximum extent of glaciation, marking an important geochemical difference between old and strongly weathered soil (S. Europe), and young, coarse grained and less weathered soil (N. Europe). The large differences in Ni levels show that it is impossible to define one background range for the whole of Europe.

\section{European Ground water Geochemistry}

While the geochemistry of surface water is documented in the EuroGeoSurveys 'Geochemical Atlas of Europe' (Salminen et al., 2005; De Vos and Tarvainen et al., 2006), the geochemistry of ground water has not yet been documented in a comparable way at the European scale. Such data are, however, urgently needed in connection with the EU Water Directive. At present the European Environmental Agency anticipates to build up a database from each Member State's water quality monitoring databases. The EGS Geochemistry Expert Group's experience, however, with previous compilations of all geochemical data in Europe, has clearly demonstrated that this attempt will face serious problems of homogeneity of the collected data, based on various sampling and analytical methods. Since, the policy of EuroGeoSurveys is to provide data of high integrity and compatible across political boundaries, the EGS Geochemistry Expert Group proposed that the Geological Surveys themselves to use their own resources and to start a Europe-wide mapping of ground water quality following the 'Geochemical Atlas of Europe' example (low density sampling, harmonised equipment and sample protocol, all analysis carried out in one laboratory only, etc.). Because ground water is not a 'simple' sample medium, and all Geological Surveys cannot provide the necessary funds, in order to obtain a first and inexpensive approximation of ground water quality at the European scale, it was decided to sample bottled water, which could easily be purchased from supermarkets by each national representative and other colleagues. It was known that the storage and preservation conditions of bottled water in supermarkets across Europe undoubtedly varied, but it was considered a worth while effort to test if this water could provide an inexpensive first approximation to ground water quality. Therefore, available bottled waters in Europe were purchased from November 2007 to March 2008, and sent to Bundesanstalt für Geowissenshaften und Rohstoffe (BGR) in Germany for analysis.

All bottled waters were stored in refrigerators, and analysed by different methods for $\mathrm{pH}, \mathrm{EC}$, $\mathrm{Ag}, \mathrm{Al}, \mathrm{As}, \mathrm{B}, \mathrm{Ba}, \mathrm{Be}, \mathrm{Bi}, \mathrm{Ca}, \mathrm{Cd}, \mathrm{Ce}, \mathrm{Co}, \mathrm{Cr}, \mathrm{Cs}, \mathrm{Cu}, \mathrm{Dy}, \mathrm{Er}, \mathrm{Eu}, \mathrm{Fe}, \mathrm{Ga}, \mathrm{Gd}, \mathrm{Ge}, \mathrm{Hf}, \mathrm{Hg}$, Ho, I, K, La, Li, Lu, Mg, Mn, Mo, Na, Nb, Nd, Ni, Pb, Pr, Rb, Sb, Sc, Se, Sm, Sn, Sr, Ta, Tb, Te, Th, Ti, Tl, Tm, U, V, W, Y, Yb, Zn, Zr, $\mathrm{Br}^{-}, \mathrm{HCO}_{3}^{-}, \mathrm{Cl}^{-}, \mathrm{F}^{-}, \mathrm{NH}_{4}{ }^{+}, \mathrm{NO}_{2}{ }^{-}, \mathrm{NO}_{3}{ }^{-}, \mathrm{PO}_{4}{ }^{3-}, \mathrm{SO}_{4}{ }^{2-}$ and $\mathrm{SiO}_{2}$. Duplicate bottled water samples were purchased from different supermarkets, and replicate and multiple analyses were performed for quality control purposes, and the estimation of measurement uncertainty. Since, bottle materials are known to affect the chemical composition of contained water, both glass and "plastic" bottles (polyethylene terephthalate, PET) of the same brand were purchased, and leaching tests were carried out. It was found that at a $\mathrm{pH}$ of 6.5 leaching of elements from bottle materials is negligible, but it becomes serious at a $\mathrm{pH}$ of 3.5, i.e., PET bottles contaminated the contained water with $\mathrm{Sb}$, and clear glass bottles with 


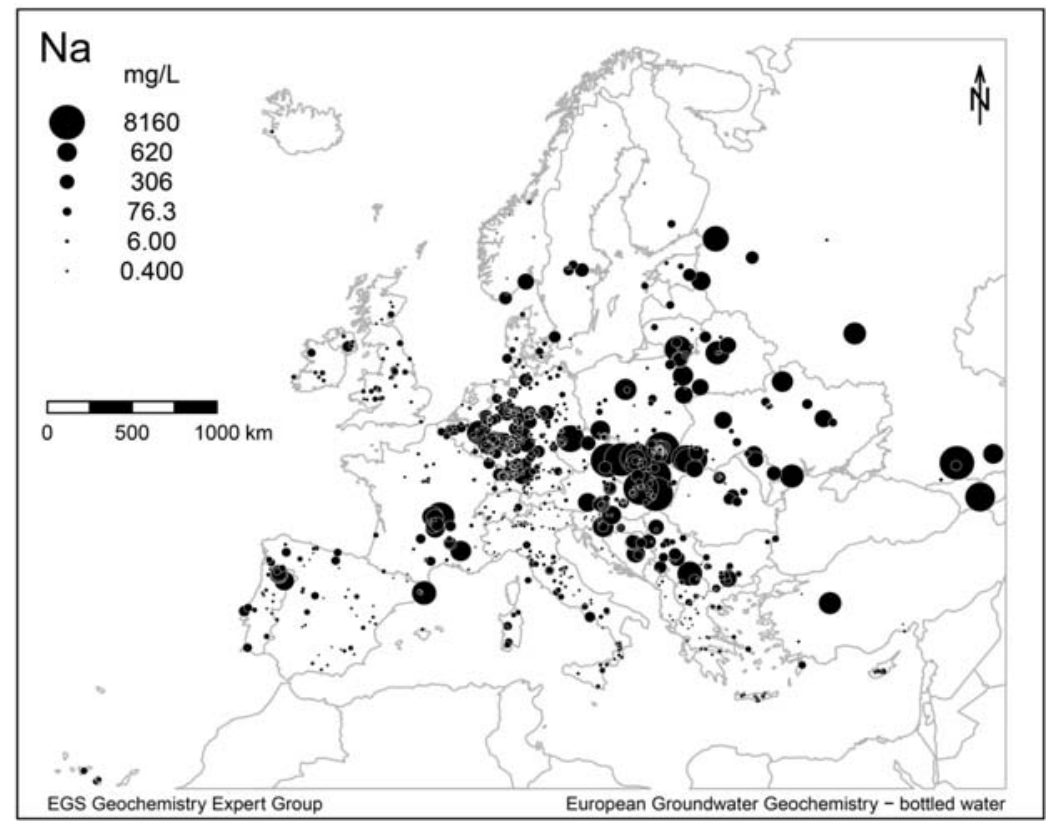

Fig. 2: Geochemical distribution of $\mathrm{Na}$ in bottled water (EGS, 2010).

Ce, Pb, Al, Zr, Ti, Hf, Th, La, Pr, Fe, Zn, Nd, Sn, Cr, Tb, Ag, Er, Gd, Bi, Sm, Y, Lu, Yb, Tm, $\mathrm{Nb}$ and $\mathrm{Cu}$, whereas green bottles leach more $\mathrm{Cr}$, Fe and $\mathrm{Zr}$. A detailed account of all procedures followed, quality control results, and leaching tests will be given in the atlas, which is under preparation (EGS, 2010). Although the analytical results are in the process of verification an example is given below.

\subsection{Distribution of sodium $(\mathrm{Na})$ in bottled water}

Sodium varies in bottled water from 0.4 to $8160 \mathrm{mg} / \mathrm{L}$, with a median of $15.5 \mathrm{mg} / \mathrm{L}(\mathrm{n}=884)$. The map of $\mathrm{Na}$ in bottled water shows high local variation (Fig. 2). This is a surprising observation. Given the high Na concentration in sea water, one may expect higher Na concentrations in coastal areas, rather than far inland. There are two possible explanations, i.e., (i) it could be related to culture, a tendency towards stronger, more mineralised, 'tasty' mineral waters in Eastern Europe, but it could also be related to (ii) geology and the deep sedimentary basins that are exploited in those areas for mineral water, giving rise to Na-rich brines. The Carpathian Mountain Range, as well as the Dinarides, is marked by high Na values. The wells with the highest $\mathrm{Na}$ concentrations (up to $8160 \mathrm{mg} / \mathrm{L}$ ) occur in Slovakia and Hungary. Wells abstracting water from Hercynian granite in France and Portugal also show somewhat increased Na concentrations, an indication of long residence time and water-rock interaction.

\section{Geochemical Atlas of Agricultural and Grazing Land Soils}

The geochemical atlas of agricultural and grazing land soils is under preparation (GEMAS). This is essentially a follow-up project of the 'Geochemical Atlas of Europe', but concentrating on soil, and the reasons for carrying out this project follow. The administration of REACH (Reg- 
istration, Evaluation and Authorisation of Chemicals), the new European Chemicals Regulation adopted in December 2006 (http://ec.europa.eu/environment/chemicals/reach/reach_intro.htm/), and the pending EU Soil Protection Directive, require additional knowledge about 'soil quality' at the European scale. REACH specifies that industry must prove that it can produce and use its substances safely. Risks, due to the exposure to a substance during production and use at the local, regional and European scale, all need to be reliably assessed. In contrast to human-made organic substances that do not occur naturally in the environment, all industries dealing with natural resources will face in the near future a number of specific questions: (i) Most of their 'products' occur also naturally - the natural background variation needs to be established, in addition to a methodology to differentiate the industrial impact from the natural geogenic background; (ii) What is the 'bioavailability' of metals and other chemical elements in soil? and (iii) What is the long-term fate of metals and other chemical elements added to soil?

The GEMAS project will deliver good quality and comparable exposure data of metals in agricultural and grazing land soil; in addition soil properties known to influence the bioavailability and toxicity of metals (and other elements) will be determined in soil at the European scale.

The sampling at a density of 1 site $/ 2500 \mathrm{~km}^{2}$ was completed at the beginning of 2009 by collecting 2211 samples of agricultural soil (Ap-horizon, 0-20 cm, regularly ploughed fields), and 2118 samples from land under permanent grass cover (grazing land soil, 0-10 cm), according to an agreed field protocol (EuroGeoSurveys Geochemistry Working Group, 2008).

All samples were shipped to the laboratory of the Geological Survey of Slovakia for sample preparation, where they were air dried, sieved to $<2 \mathrm{~mm}$ using a nylon screen, homogenised and split to subsamples for analysis. They are analysed for (1) 53 chemical elements following an aqua regia extraction, (2) $\mathrm{pH}$ in $\mathrm{CaCl}_{2}$, TOC, LOI, grain size (on a selection of samples), total $\mathrm{C}$ and total S, (3) total concentrations of 39 elements by X-ray fluorescence, (4) $\mathrm{Pb}$ and $\mathrm{Sr}$ isotopes, (5) prediction of soil properties by mid infrared (MIR) measurements and (6) determination of $\mathrm{K}_{\mathrm{d}}$ values for selected elements on selected samples. The aqua regia results were received in September 2009 and were subjected to a rigorous quality control procedure before their acceptance (Reimann et al., 2009). Because of the complexity of the project, and confidentiality of results, the Geochemical Atlas will be ready by 2013, and an example is given below.

\subsection{Distribution of strontium (Sr) in agricultural soil}

Natural variation of $\mathrm{Sr}$ is large (4 orders of magnitude) and can be reliably mapped as is shown in Figure 3. Nature, geology and climate are the major driving forces for its distribution patterns, while anthropogenic anomalies, as input by fertilisers are not recognisable at this scale. It is clearly indicated that there is not one background value for a sizeable area. Strontium, together with other elements, shows substantially lower concentrations in North than in South European agricultural soil. Surprisingly, recent volcanism (Cyprus, Sicily, mainland Italy) and active fault zones and plate margins are often better indicated by $\mathrm{Sr}$ anomalies than some of the major limestone areas, except those of eastern Spain, southern France, Italy, and Paris Basin in France.

\section{Conclusions}

European wide geochemical maps are designed to reveal large continental scale geochemical anomalies or patterns; it is stressed that patterns of local significance cannot be observed in such low density sampling surveys. Nevertheless, continental scale geochemical surveys pro- 


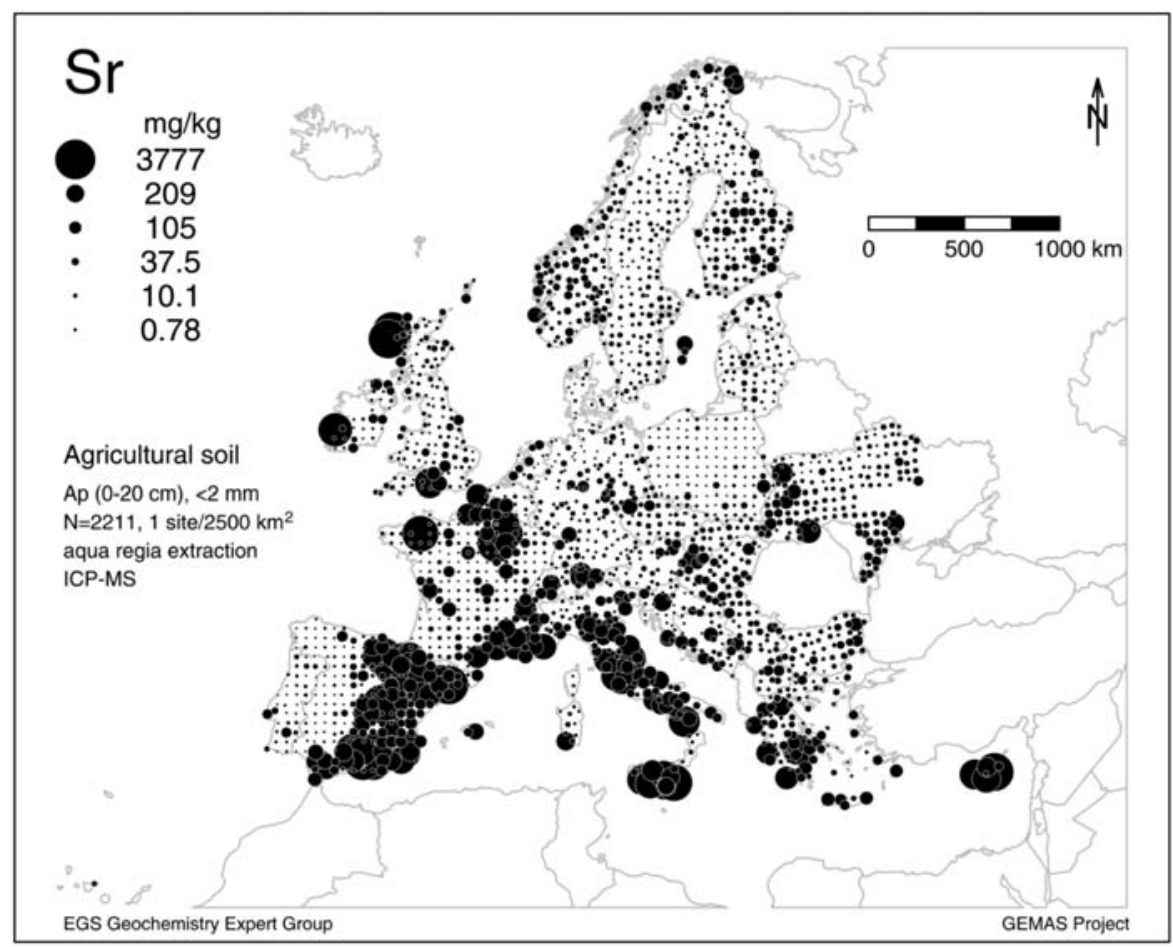

Fig. 3: Geochemical distribution of aqua regia extractable $\mathrm{Sr}$ in the $<2 \mathrm{~mm}$ fraction of agricultural soil (0$20 \mathrm{~cm}$ ) (Reimann et al., 2009, Fig. 7, p.28).

vide us with invaluable information about the natural and human induced concentrations of chemical elements in sample media of the near-surface environment, where we live on, grow our crops, raise our livestock, and from which we extract our drinking water, and other raw materials, including mineral wealth. Our quality of life and health depend, in fact, on the chemical composition of water (surface or ground water) and soil, whether residual (developed directly on bedrock) or alluvial (transported by river water and deposited during flood episodes on floodplains).

The European wide projects, carried out by the EuroGeoSurveys Geochemistry Expert Group, have, therefore, demonstrated that low-density geochemical mapping can provide the needed information about the geochemical background variation in natural soil, stream water, ground water, stream and overbank or floodplain sediments. Thus, the EuroGeoSurveys 'Geochemical Atlases of Europe' provide European policy-makers, researchers, applied geochemists and citizens alike with sound data about the geochemical state of environmental media that our standard of living and health are closely related to. They also provide the 'geochemical baselines' against which the next generations will quantify changes, whether natural or human-made.

Production of such harmonised strategic baseline geochemical databases and maps is only possible, because of standardisation of all procedures of sampling, sample preparation, chemical analysis and data management across political boundaries. Without harmonisation of methods, it is impossible to produce meaningful continental scale geochemical databases and maps. It is, therefore, important for scientists working for the production of European wide databases and 
maps to understand the concept of harmonisation of methods, and to apply it in their work. Otherwise, valuable time, effort and financial resources will be wasted in the production of incompatible data across political boundaries.

Finally, geochemical maps at a variety of scales are needed for different purposes (Reimann et al., 2009). However, low density geochemical mapping lays the foundations for regional geochemistry and research in environmental sciences (Smith and Reimann, 2008). The relative importance of a variety of geochemical processes that govern the geochemistry at the Earth's surface can only be distinguished and evaluated from the study of continental or global scale maps, since many processes will not be recognised at the too detailed local scale.

\section{Acknowledgments}

This is a combined effort by members of the EuroGeoSurveys Geochemistry Expert Group, i.e., Austria: Albert Schedl, Heinz Reitner, Edith Haslinger, Peter Filzmoser; Belgium: Walter De Vos; Bosnia \& Herzegovina: Hazim Hrvatovic; Neven Miosic, Ferid Skopljak, Natalija Samardzic; Bulgaria: Valeri Trendavilov; Croatia: Josip Halamić, Ajka Šorša, Stjepan Husnjak; Czech Republic: Miloslav Duris; Cyprus: Zomenia Zomeni; Denmark: Vibeke Ernstsen; Estonia: Jaan Kivisilla, Walter Petersell; Finland: Timo Tarvainen, Mikael Eklund; France: Ignace Salpeteur; F.Y.R.O.M.: Trajce Stafilov; Germany: Manfred Birke, Rainer Hoffmann, Jens Utermann; Hellas: Alecos Demetriades; Hungary: Gyozo Jordan, Ubul Fugedi, Laszlo Kuti; Ireland: Patrick O'Connor, Fionnuala Ni Mhairtin, Vincent Gallagher; Italy: Benedetto De Vivo, Annamaria Lima, Stefano Albanese, Enrico Dinelli, Domenico Cicchella, Paolo Valera; Latvia: Aivars Gilucis; Lithuania: Virgilija Gregorauskiene; Luxembourg: Robert Maquil; Netherlands, The: Gerben Mol; Norway: Clemens Reimann, Rolf Tore Ottesen, Tore Volden, Ola A. Eggen, Arnold Arnoldussen; Poland: Anna Pasieczna, Aleksandra Dusza, Paweł Kwecko; Portugal: Maria Joao Batista, Cátia Prazeres; Serbia: Aleksandra Gulan, Dragana Vidojević; Slovakia: Igor Slaninka, Peter Sefcik, Daniela Mackovych, Silvester Pramuka; Slovenia: Mateja Gosar; Spain: Juan Locutura, Alejandro Bel-lan; Sweden: Madelen Andersson, Kaj Lax; Switzerland: Peter Hayoz, Reto Giulio Meuli; Ukraine: Boris I. Malyuk, Volodymyr Klos; United Kingdom: Dee Flight, Andreas Scheib, Mick Strutt, Paul McDonnell. The GEMAS project is sponsored by the European Association of Metals (Eurometaux - http://www.eurometaux.org/) for sample preparation and parts of the analytical work. The support of BGR for the provision of free analysis for all projects is acknowledged. The paper is published by permission of the I.G.M.E. General Director.

\section{References}

Bölviken, B., Bogen, J., Demetriades, A., De Vos, W., Ebbing, J., Hindel, R., Langedal, M., Locutura, J., O’Connor, P., Ottesen, R.T., Pulkkinen, E., Salminen, R., Schermann, O., Swennen, R., Van der Sluys, J. \& Volden, T., 1996. Regional geochemical mapping of Western Europe towards the year 2000. Journal of Geochemical Explororation, 56, 141-166.

Darnley, A.G., 1997. A global geochemical reference network: the foundation for geochemical baselines. In: K. Marsina \& K. Vrana (Editors), Environmental Geochemical Baseline Mapping in Europe. Special Issue, Journal of Geochemical Exploration, 60(1), 1-5.

Darnley, A.G., Björklund A., Bølviken, B., Gustavsson, N, Koval, P.V., Plant, J.A., Steenfelt, A,, Tauchid, M., Xuejing, X., Garrett, R.G. \& Hall G.E.M., 1995. A global geochemical database for environmental and resource management. Final report of IGCP Project 259. Earth Sciences, 
19, UNESCO Publishing, Paris, 122 pp.

Demetriades, A., 1998. Global Geochemical Baselines: A fundamental international project for environmental management. Bulletin of the Geological Society of Greece, 32(1), 321-329.

Demetriades, A., De Vivo, B., Ander, E.L., Bidovec, M., Lima, A., Pirc, S., Reeder, S., Siewers, U, Smith, B., Albanese, S., Batista, M.J., Bel-Ian, A., Birke, M., Breward, N., De Vos, W., Duris, M., Gravesen, P., Gregorauskiene, V., Halamic, J., Jordan, G., Lax, K., Locutura, J., O’Connor, P.J., Pasieczna, A., Slaninka, I., Tarvainen, T., Gilulis, A., Heitzmann, P., Klaver, G., Klein, P., LIs, J., Marsina, K., Mazreku, A., Ottesen, R.T., Petersell, V., Salminen, R., Salpeteur, I., Sandstrom, H., Shaw, R., Steenfelt, A. \& Taylor, H., 2008. The EuroGeoSurveys Geochemical Atlas of Europe: Stream water geochemistry. In: G. Migiros, G. Stamatis \& G. Stournaras (Editors), Proceedings $8^{\text {th }}$ International Hydrogeological Congress of Greece - 3rd MEM Workshop on fissured rocks hydrology. Geological Society of Greece, Athens, Volume 1, 237-250.

De Vos W., Tarvainen T. (Chief Editors), Salminen R., Reeder S., De Vivo B., Demetriades A., Pirc S., Batista M.J., Marsina K., Ottesen R.T., O’Connor P.J., Bidovec M., Lima A., Siewers U., Smith B., Taylor H., Shaw R., Salpeteur I., Gregorauskiene V., Halamic J., Slaninka I., Lax K., Gravesen P., Birke M., Breward N., Ander E.L., Jordan G., Duris M., Klein P., Locutura J., Bellan A., Pasieczna A., Lis J., Mazreku A., Gilucis A., Heitzmann P., Klaver G. \& Petersell V. 2006. Geochemical Atlas of Europe. Part 2 - Interpretation of Geochemical Maps, Additional Tables, Figures, Maps, and Related Publications. Geological Survey of Finland, Espoo, 692 pp. Available online at: http://www.gtk.fi/publ/foregsatlas/ (last accessed on 17/1/2010).

EuroGeoSurveys Geochemistry Working Group, 2008. EuroGeoSurveys Geochemical mapping of agricultural and grazing land soil of Europe (GEMAS) - Field manual. Geological Survey of Norway, Trondheim, NGU Report 2008.038, 46 pp. Available online at: http://www.ngu.no/en$\mathrm{gb} / \mathrm{hm} /$ Publications/Reports/2008/2008-038/ (last accessed on 17/1/2010).

EGS (EuroGeoSurveys), 2010. EuroGeoSurveys Geochemistry Expert Group's European Ground water Geochemistry Part 1: Bottled Water. Schweizerbart'sche Verlagsbuchhandlung, Stuttgart, in press.

Encyclopaedia Britannica, 2010. Encyclopadia Britannica 2010 Ultimate Reference Suite DVD. Encyclopædia Britannica, Chicago.

Fedele, L., Plant, J.A., De Vivo, B. \& Lima, A., 2008. The rare earth element distribution over Europe: geogenic and anthropogenic sources. Geochemistry: Exploration, Environment, Analysis, 8(1), 3-18.

Garrett, R.G., Reimann, C., Smith, D.B. \& Xie Xuejing, 2008. From geochemical prospecting to international geochemical mapping: a historical overview. Geochemistry, Exploration, Environment, Analysis, (Arthur Darnley issue), 8, 205-217.

Lima, A., Plant, J.A., De Vivo, B., Tarvainen, T., Albanese, S. \& Cicchela, D., 2008. Interpolation methods for geochemical maps: a comparative study using arsenic data from European stream waters. Geochemistry: Exploration, Environment, Analysis, 8(1), 41-48.

Reimann, C., Demetriades, A. Eggen, O.A., Filzmoser, P. \& the EuroGeoSurveys Geochemistry Expert Group, 2009. The EuroGeoSurveys geochemical mapping of agricultural and grazing land soils project (GEMAS) - Evaluation of quality control results of aqua regia extraction analysis. Geological Survey of Norway, Trondheim, NGU Report 2009.049, 94 pp. Available online at: http://www.ngu.no/en-gb/hm/Publications/Reports/2009/2009-049/ (last accessed on 17/1/2010).

Reimann, C., Matschullat, J., Birke, M., \& Salminen, R., 2009. Arsenic distribution in the environment: the effects of scale. Applied Geochemistry, 24, 1147-1167.

Salminen R. (Chief Editor), Batista M.J., Bidovec M., Demetriades A., De Vivo B., De Vos W., 
Duris M., Gilucis A., Gregorauskiene V., Halamic J., Heitzmann P., Lima A., Jordan G., Klaver G., Klein P., Lis J., Locutura J., Marsina K., Mazreku A., O’Connor P.J., Olsson S.Å., Ottesen R.T., Petersell V., Plant J.A., Reeder S., Salpeteur I., Sandström H., Siewers U., Steenfelt A. and Tarvainen T. 2005. FOREGS Geochemical Atlas of Europe, Part 1: Background Information, Methodology and Maps. Geological Survey of Finland, Espoo, 526 pp. Available online at: http://www.gtk.fi/publ/foregsatlas/ (last accessed on 17/1/2010).

Smith, D.B. \& Reimann, C., 2008. Low density geochemical mapping and the robustness of geochemical patterns. Geochemistry, Exploration, Environment, Analysis, (Arthur Darnley issue), 8, 219-227. 